\title{
HOW IMPORTANT IS GAMBLING IN NATIONAL GDP: CASE STUDY FROM AUSTRIA, CROATIA, ITALY AND SLOVENIA
}

\author{
Andrej Raspor ${ }^{1}$, Iva Bulatović ${ }^{2}$, Ana Stranjančević ${ }^{2}$, Darko Lacmanović ${ }^{2}$
}

date of paper receipt:

11.3.2019.

Original Article date of sending to review:

14.03.2019.

doi:10.2478/eoik-2019-0004 date of review receipt:

27.3.2019.

${ }^{1}$ School of Advanced Social Studies, Slovenia DOBA Faculty of Applied Business and Social Studies, Slovenia ${ }^{2}$ University Mediterranean Faculty for tourism Montenegro Tourism School, Montenegro

\begin{abstract}
Purpose - The situation in the field of gambling is changing due to the rise of Internet and Mobile gambling. In general gambling consumption is increasing every year, but the distribution of consumption has radically changed from Land Based gambling to Remote gambling. The purpose of this article is to present an overview of the world gambling industry and a specific overview in Austria, Croatia, Italy and Slovenia in order to find some main similarities and differences in observed period.

Design/Methodology/Approach - The main research question is How important is gambling for the involved countries and what proportion of the national GDP does the gambling revenue account for? This paper presents the analysis of five statistical databases for the last sixteen years in order to find out some patterns, cyclical or seasonal features or other significant information that allows us to do forecasting of the future revenue with a certain degree of accuracy. We have systematically searched and collected data from the World Bank and the National Statistical Offices websites of the given countries. Statistical methods were used for benchmark analysis, while Box and Jenkins approach and ARIMA modelling were used for forecasting.

Findings - The smallest increase was recorded in Slovenia and the largest in Italy. The same effects were also observed in the GDP of these countries. Thus, the state budgets of Croatia and Italy are increasingly dependent on gambling taxes. It also has negative wages. The gambling addictions among the locals have become more frequent as well.

Originality of the research - The article shows the forecasts of the gambling revenue and its share in the GDP by 2027. We want to alert decision makers to adopt appropriate policies. States need to rethink their views on gambling and the excessive dependence of the state budget on gambling taxes. This is the first time a single comparative analysis of these countries and the above mentioned forecast has been conducted.
\end{abstract}

\section{Keywords:}

gambling revenue, GDP, forecasting, time-series, Box and Jenkins approach, ARIMA modelling. 


\section{INTRODUCTION}

The phenomenon of gambling is not new. It can be defined as playing games with an uncertain result that is determined (at least partly) by chance (Bolen \& Boyd, 1968) and it can be claimed to be as old as humanity itself (Kuss \& Griffiths, 2012). From prehistoric to modern times we knew only Classical and Special or casino gambling. Internet gambling era started in 1994 when the Antiguan government passed a law that allowed online casinos to be established within its borders (Cotte \& Latour, 2008). The ability to partake in online gambling is a result of technological advances of the Internet, gambling software and the secure payment systems. It was announced that the global gambling market was 463 billion USD in 2016. Casinos are according to Bloomberg.com among the largest industries on earth - 12th place in 2016 (Bloomberg, 2016).

Three central arguments made in this article are: (1) Gambling is an important industry in both the tourism and entertainment. (2) Comparison of development in two Countries with long capitalist tradition and two Post-Communist Countries. (3) Countries benefit greatly from gambling as gambling revenues represent a significant part of GDP.

The main research question is How important is gambling for the involved countries and what proportion of the national GDP does the gambling revenue account for?

The paper is organised in the following manner. Section one covers the theoretical and historical background of gambling in the involved countries. Section two presents the methodology used in the article. Section three considers the theoretical background and research results and discusses the research question. Section four offers the main paper conclusion.

\section{GAMBLING INDUSTRY OVERVIEW}

\section{WORLD'S BIGGEST GAMBLERS}

Gambling is a major industry in the United States and one that has experienced substantial growth in the recent decades. However, after a long and steady increase gambling and gambling revenues started to decline in 2008 (Horváth \& Paap, 2012).

World index of growth in the gambling industry from 2001 (220 billion USD) to 2016 (450 billion USD) ('The world's biggest gamblers', 2017) is 2.05 (Table 1 and Figure 2-4).

It is expected for the global casino gambling market to grow at a Compound Annual Growth Rate (CAGR) of 10.16\% during the period 2017 - 2021 (Wood, 2017) and the revenue from gambling is expected to reach 635 billion USD by 2022 (Pempus, 2016). Asia-Pacific is the major region growing in this market due to the emergence of major casinos in the region that are operated by the US-based companies which will divert some of the US overseas-derived business in the region. Gambling is in the forefront because many countries are looking to beef up their respective tourism industries. Las Vegas and Macao may be synonymous with gambling, but the industry's biggest expo is actually held in London, Gibraltar and Malta. Online gambling is the industry's fastestgrowing sector and has accounted for $11 \%$ of the 385 billion USD of gambling profits posted in 2016 ('The world's biggest gamblers', 2017). Other segments have shown a stable growth.

To the general public, Australia hardly leaps to mind as a gambling hotbed. According to $\mathrm{H} 2$ Gambling Capital (H2G), a consultancy, betting losses per resident adult there have amounted to 990 USD last year. That is $40 \%$ higher than Singapore ('The world's biggest gamblers', 2017). For this article the behaviour of Italian, Austrian and Croatian citizens is important. Italians are in the ninth place with 390 USD, half of this on slot machines and Video lottery terminal (VLT). 
Table 1. World Revenue from gambling and betting and GDP (billion USD)

\begin{tabular}{|c|c|c|c|c|c|}
\hline Year & $\begin{array}{l}\text { Revenue from } \\
\text { gambling and } \\
\text { betting }\end{array}$ & GDP & $\begin{array}{l}\text { Gambling and } \\
\text { betting in GDP }\end{array}$ & $\begin{array}{l}\text { Basic gambling } \\
\text { Income Index } \\
\quad(2001)\end{array}$ & $\begin{array}{c}\text { Basic index } \\
\text { of gambling } \\
\text { revenues in GDP } \\
(2001)\end{array}$ \\
\hline 2001 & 220 & 33,336 & $0.66 \%$ & 1.00 & 1.00 \\
\hline 2002 & 235 & 34,612 & $0.68 \%$ & 1.07 & 1.03 \\
\hline 2003 & 265 & 38,867 & $0.68 \%$ & 1.20 & 1.03 \\
\hline 2004 & 300 & 43,771 & $0.69 \%$ & 1.36 & 1.04 \\
\hline 2005 & 310 & 47,386 & $0.65 \%$ & 1.41 & 0.99 \\
\hline 2006 & 325 & 51,307 & $0.63 \%$ & 1.48 & 0.96 \\
\hline 2007 & 355 & 57,793 & $0.61 \%$ & 1.61 & 0.93 \\
\hline 2008 & 370 & 63,386 & $0.58 \%$ & 1.68 & 0.88 \\
\hline 2009 & 370 & 60,087 & $0.62 \%$ & 1.68 & 0.93 \\
\hline 2010 & 385 & 65,906 & $0.58 \%$ & 1.75 & 0.89 \\
\hline 2011 & 430 & 73,242 & $0.59 \%$ & 1.95 & 0.89 \\
\hline 2012 & 440 & 74,802 & $0.59 \%$ & 2.00 & 0.89 \\
\hline 2013 & 445 & 76,925 & $0.58 \%$ & 2.02 & 0.88 \\
\hline 2014 & 445 & 78,870 & $0.56 \%$ & 2.02 & 0.85 \\
\hline 2015 & 430 & 74,510 & $0.58 \%$ & 1.95 & 0.87 \\
\hline 2016 & 450 & 75,544 & $0.60 \%$ & 2.05 & 0.90 \\
\hline Average & 361 & 59,396 & $0.62 \%$ & & \\
\hline
\end{tabular}

Source: (“H2 Gambling Capital” 2017; own research)

The online gambling industry has now entered its official 20th year of existence (Fontenot, 2016). The first recorded online casino to accept a wager was based in Antigua in 1996. Online gambling has become exponentially popular with the explosion of internet access over the last two decades (Krogulecki, 2017). However, data detailing how much do the individuals play and spend on online gaming are not readily available. Some have speculated on the causes of this growth. For example, it has been suggested that online poker, a game that draws many online players, and betting exchanges, has grown for three reasons: they provide financial value for the gambler without a casino's house edge or bookmakers' mark-up on the odds; gamblers may win because the games require some element of skill when bets are placed and gamblers may compete directly with other gamblers instead of a pre-programmed machine with fixed odds (Griffiths, Parke, Wood, \& Parke, 2006).

Legislation over the past several decades has resulted in greater accessibility and social acceptance of gambling. One of the most significant changes to the gambling in the past 15 years has been the increased availability of interactive gambling (Gainsbury et al., 2015). Approximately 85 nations had elected to legalize online gaming as of 2011 (Stewart \& Gray, 2011) and in 2017 this number is actually around 90 . Stewart \& Gray have divided those countries into three groups with similar qualities or policy characteristics. The first group consists of small jurisdictions in the Western Hemisphere, which offer low-cost licensing to operators with low tax rates and little or no regulatory scrutiny; they view online gambling strictly as a means of economic development. The second group consists of small jurisdictions in Europe that also regulate online gaming for economic development but have more regulations compared to the first group. The final group consists of larger, developed countries (such as the United Kingdom). Those that fall into the third category face the challenge of their markets being invaded by websites originating from the jurisdiction of the first two groups (Stewart \& Gray, 2011).

The top five emerging trends driving the global online gambling market according to Technavio media and entertainment research analysts are (Maida, 2016):

Growing numbers of online women gamblers, 
- Increasing penetration of credit and debit cards,

- Changing consumer gambling habits,

- Use of alternative options to cash,

- Changing marketing strategies.

There has been a significant change in consumer behaviour in the global online gambling market. The increase in the popularity of gambling apps and social gambling are the major factors that are expected to propel market growth during the forecast period (Maida, 2016). Many industry insiders see VR gambling as one of the key areas that gambling operators are investing in to 'hook' the Generation Y 'millennials' into gambling. Today's modern screenagers love technology and do not appear to have any hang-ups about using wearable technology including Fitbit and the Apple Watch (Griffiths, 2017).

The casino industry contributes significantly to a country's economy. It accounts for $0.45 \%$ of the US GDP, which is slightly less than the world average (0.56 \%) (Table 1$)$. The revenue generated by casinos can be used to support economic activities such as building schools and hospitals. The casino industry has the potential to create numerous jobs considering the number of individuals required (Wood, 2017).

\section{AUSTRIA}

Since the time of the Austro-Hungarian monarchy, there is a rich gambling history in Austria. Games of chance, in general, were prohibited in the Austro-Hungarian Monarchy. In 1790 the first casino was opened and the town got the name of Austrian Nice, which happened 16 years after the closing of the casino in Venice. Gambling was generally prohibited after the World War I (Cabot, Thompson, W. N., Tottenham, \& Braunlich, 1999).

In modern Austria, there is a very long history of casino entertainment and that kind of entertainment has become an important part of their tourist market since 1930. During the $1934-1945$ period two casinos were opened, one seasonal Casino in the Alps, called "Alpencasino", and another in the city of Baden-Baden (during the Second World War in 1945) (Ibid).

The company "Österreichische Casino A.G." got reissued a government license in 1950 and that was the start of the rapid expansion to other cities in the country. In 1967 company changed its name into "Österreichische Spielbanken AG", and in 1985 got the new modern name "Casinos Austria" which is still the name of the company. In mid-to-late 1980s this company began to expand its business to the other countries through management contracts and international consulting and has realized more than 300 casino projects until today (it owns land based casinos, shipboard casinos and video lottery terminals) (Ibid).

Gambling and gaming market in Austria is stable (Table 2, Figure 2 - 4). In the period from 2001 to 2016, there is a constant growing (index 1.3) and this growth continues in a strong manner in 2016. Betting and online casino showed the biggest growth. Average share of Gambling and betting activities in the GDP (in the period $2001-2016$ ) is $0.45 \%$ and looking at the growth index (base in 2001) in 2017 a coefficient of 0.82 is realized.

The game and betting stakes rose by $+9.9 \%$ in 2016 , reaching 17.9 million EUR. The gross-(BSE) rose by $+3.8 \%$ to reach 1,610 million EUR. The strongest growth is recorded in Sportwetten and online gaming with revenue approximately 35 and 33 million EUR, respectively. Game banks achieved the revenue of 12 million EUR ("Glücksspiel \& amp; Sportwetten in Österreich 2017" 2017). 
Table 2. Austria Revenue from gambling and betting and GDP (million EUR)

\begin{tabular}{|c|c|c|c|c|c|}
\hline Year & $\begin{array}{l}\text { Revenue from } \\
\text { gambling and } \\
\text { betting }\end{array}$ & GDP & $\begin{array}{l}\text { Gambling and } \\
\text { betting in GDP }\end{array}$ & $\begin{array}{l}\text { Basic gambling } \\
\text { Income Index } \\
\quad(2001)\end{array}$ & $\begin{array}{c}\text { Basic index } \\
\text { of gambling } \\
\text { revenues in GDP } \\
(2001)\end{array}$ \\
\hline 2001 & 1,237 & 220,096 & $0.56 \%$ & 1.00 & 1.00 \\
\hline 2002 & 1,182 & 226,303 & $0.52 \%$ & 0.96 & 0.93 \\
\hline 2003 & 1,161 & 230,999 & $0.50 \%$ & 0.94 & 0.89 \\
\hline 2004 & 1,175 & 241,505 & $0.49 \%$ & 0.95 & 0.87 \\
\hline 2005 & 1,172 & 253,009 & $0.46 \%$ & 0.95 & 0.82 \\
\hline 2006 & 1,174 & 266,478 & $0.44 \%$ & 0.95 & 0.78 \\
\hline 2007 & 1,125 & 282,347 & $0.40 \%$ & 0.91 & 0.71 \\
\hline 2008 & 1,201 & 291,930 & $0.41 \%$ & 0.97 & 0.73 \\
\hline 2009 & 1,263 & 286,188 & $0.44 \%$ & 1.02 & 0.79 \\
\hline 2010 & 1,198 & 294,628 & $0.41 \%$ & 0.97 & 0.72 \\
\hline 2011 & 1,374 & 308,630 & $0.45 \%$ & 1.11 & 0.79 \\
\hline 2012 & 1,324 & 317,117 & $0.42 \%$ & 1.07 & 0.74 \\
\hline 2013 & 1,271 & 322,539 & $0.39 \%$ & 1.03 & 0.70 \\
\hline 2014 & 1,305 & 330,418 & $0.40 \%$ & 1.05 & 0.70 \\
\hline 2015 & 1,517 & 339,896 & $0.45 \%$ & 1.23 & 0.79 \\
\hline 2016 & 1,610 & 349,344 & $0.46 \%$ & 1.30 & 0.82 \\
\hline Average & 1,268 & 285,089 & $0.45 \%$ & & \\
\hline
\end{tabular}

Source: (“BMF - Bundesministerium Für Finanzen” 2017; own research)

Austria has 12 casinos in tourist destinations (Casinos Austria, 2017). The entry is permitted to adults only (aged 18 or above) who have provided adequate proof of identity and who are not subject to an entry ban. The frequency of visits to casinos and gambling intensity is monitored by the licensee. The individuals who are identified as potentially at a risk of threat to their minimum subsistence income are subject to credit checks by the casino (Schwartz \& Schwartz Huber-Medek und Partner, 2016). For this reason Austrians also go to foreign casinos (Switzerland, Germany, Slovenia and Czech Republic). After the renovation in 1990 - 2000, Casino Austria does not invest in casinos.

In the lottery market, there is a monopoly with only one license available. However, in the casino market, there is an oligopoly, with 15 casino licenses being available. Provincial games with slot machines are not part of the gambling monopoly (salons with 10 to 50 slot machines). In the license for lottery games, there is a right to be offering "electronic lotteries" which includes any gambling product online (Schwartz \& Schwartz Huber-Medek und Partner, 2016).

Casino is domestic or more tourist foreign-oriented (Switzerland, Italy, Germany, Slovenia) and Lottery, Slot club and Online is more domestic oriented.

\section{CROATIA}

In the former communist Yugoslavia, the first legislation on gambling was introduced in 1963 in Opatija in Croatia, where the first casino in the East Europe was opened (Luin, 2004).

This casino was intended for foreign tourists only. Casino gambling in Yugoslavia was allowed for pragmatic reasons - the lack of the "western currency" - and this has proven significant for the future development of this economic activity, especially as an "export-oriented" industry closely connected to tourism. Until the 1980's casino gambling was accepted as a supplement to the existing tourist capacities and offered to the "elite" foreign clients (Ibid).

The legislation was liberated after independence in 1991, which was important for the local 
population who were allowed to visit casinos (Ibid).

The only right to organize games of chance in the Republic of Croatia belongs to the Croatian Lottery d.o.o. Other trading companies based in the Republic of Croatia may also be allowed to organize games in casino and games of betting by the decision of the Government and the approval of the Ministry of Finance and after a public tender.

In 2007 the first concessions were granted for the organization of games of chance in automated clubs, and by the end of 2014, the Ministry of Finance and Government allowed 29 new concessions (increase from 19 to 48) (Puljiz, 2015). By statistical data, at the end of 2016 there are 2500 bookmakers, 15 casinos in 12 cities, 219 automated clubs ('Pošast koja uništava sve više mladih u Hrvatskoj i njihove obitelji', 2016), a "State lottery" ('Hrvatska Lutrija, 2017) and at least 5 online casinos. In 2015 the first legal online casino was opened ('Otvoren prvi internet casino u Hrvatskoj', 2015). Opening a gambling club in Croatia is not complicated and can be placed anywhere without any restrictions. The holder of the concession can open as many gambling clubs as they can.

Table 3. Croatia Revenue from gambling and betting and GDP (million EUR)

\begin{tabular}{|c|c|c|c|c|c|c|c|}
\hline Year & $\begin{array}{c}\text { Number of } \\
\text { company }\end{array}$ & Employees & $\begin{array}{l}\text { Revenue } \\
\text { from } \\
\text { gambling } \\
\text { and betting }\end{array}$ & GDP & $\begin{array}{l}\text { Gambling } \\
\text { and betting } \\
\text { in GDP }\end{array}$ & $\begin{array}{c}\text { Basic } \\
\text { gambling } \\
\text { Income } \\
\text { Index } \\
(2001)\end{array}$ & $\begin{array}{l}\text { Basic index } \\
\text { of gambling } \\
\text { revenues in } \\
\text { GDP (2001) }\end{array}$ \\
\hline 2001 & 70 & 1,941 & 89 & 25,965 & $0.34 \%$ & 1.00 & 1.00 \\
\hline 2002 & 75 & 2,622 & 144 & 28,542 & $0.50 \%$ & 1.62 & 1.47 \\
\hline 2003 & 77 & 3,463 & 171 & 30,703 & $0.56 \%$ & 1.93 & 1.63 \\
\hline 2004 & 75 & 4,368 & 221 & 33,465 & $0.66 \%$ & 2.48 & 1.93 \\
\hline 2005 & 72 & 5,397 & 283 & 36,508 & $0.78 \%$ & 3.19 & 2.27 \\
\hline 2006 & 74 & 5,761 & 203 & 40,198 & $0.51 \%$ & 2.29 & 1.48 \\
\hline 2007 & 85 & 6,503 & 288 & 43,926 & $0.65 \%$ & 3.24 & 1.91 \\
\hline 2008 & 99 & 7,664 & 362 & 48,130 & $0.75 \%$ & 4.07 & 2.20 \\
\hline 2009 & 88 & 6,397 & 276 & 45,091 & $0.61 \%$ & 3.10 & 1.79 \\
\hline 2010 & 92 & 6,644 & 261 & 45,004 & $0.58 \%$ & 2.94 & 1.70 \\
\hline 2011 & 91 & 6,525 & 288 & 44,709 & $0.65 \%$ & 3.25 & 1.89 \\
\hline 2012 & 76 & 5,598 & 243 & 43,934 & $0.55 \%$ & 2.74 & 1.62 \\
\hline 2013 & 78 & 6,070 & 306 & 43,487 & $0.70 \%$ & 3.45 & 2.06 \\
\hline 2014 & 82 & 5,869 & 317 & 42,978 & $0.74 \%$ & 3.57 & 2.16 \\
\hline 2015 & 73 & 5,254 & 269 & 44,068 & $0.61 \%$ & 3.02 & 1.78 \\
\hline 2016 & 68 & 6,060 & 354 & 45,819 & $0.77 \%$ & 3.98 & 2.26 \\
\hline Average & 80 & 5,384 & 255 & 40,158 & $0.62 \%$ & & \\
\hline
\end{tabular}

Source: (Republic of Croatia Croatian Bureau of Statistics 2017; own research)

In 2016, 353 million EUR were realised in Croatia (Republic of Croatia Croatian Bureau of Statistics 2017;). From 2001 to 2016 (Table 3, Figure 2 - 4), there is a high growth (index 4.0). Average share of gambling and betting activities in the GDP (in the period $2001-2016$ ) is $0.623 \%$, i.e. in terms of the growth index (base in 2001) and in 2017 the coefficient 2.26 is realized. While the number of gambling companies remains unchanged, the number of employees has increased 3 times.

A big share of the market is formed by the bookmakers. In the famous tourist destinations (such as Dubrovnik, Pula, Zadar, Zagreb) there are casinos for tourists or foreigners (for example Italians in Istria). Other is for the domestic market. In Croatia, casinos are renovated in the major tourist resorts and the managers and owners are frequently foreigners.

Therefore gambling and gambling-related problems among Croatian youths are present (Ricijaš, Dodig Hundrić, Huić, \& Kranželić, 2016)penologiju i poremećaje u ponašanju"','id":"ITEM- 


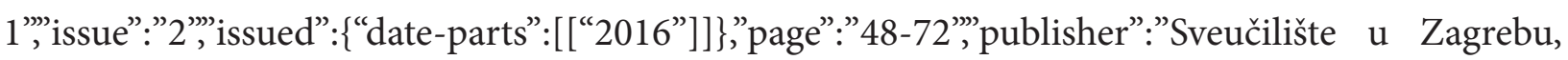
Edukacijsko-rehabilitacijski fakultet"',title":"Youth Gambling in Croatia-Frequency of Gambling and the Occurrence of Problem Gambling','type":"'article-journal',"volume":"24"\},"uris":[“http:// www.mendeley.com/documents/?uuid=5a1407fc-bc2f-4d9a-8151-f9f49f6a551c","http://www. mendeley.com/documents/?uuid=6824cb99-8c5b-4afb-9570-f718926ce63f”]\}],"mendeley":\{“form attedCitation":"(Ricijaš, Dodig Hundrić, Huić, \& Kranželić, 2016. Problematic gambling is present in young and student population. In Croatia, the gambling market is liberalized and the authorities do not care that we have already recorded about 100,000 gambling addicts ('Pošast koja uništava sve više mladih u Hrvatskoj i njihove obitelji', 2016).

Casinos in major tourist resorts are more foreign tourist oriented (Italy) and Lottery, Slot clubs and Online casinos are more domestic oriented.

\section{ITALY}

Gambling in Italy has existed for centuries in many forms and dates to the days of the Roman Empire, with games such as Ludus Duodecim Scriptorum, a predecessor to the modern backgammon. This game in particular became popular among the Roman legionnaires and due to them the game came to the other European countries.

In 1638 in Venice the first gambling house "Ridotto" was opened. It was sanctioned by the government with the purpose to be controlled by citizens. The admission to that gambling house was free, but only rich people could afford to play, due to high stakes. They used to play Biribi (similar to lottery) and Bassett which had a very high house edge. "Ridotto" was closed 1774 due to the growth of popularity of the closed gambling clubs called "casinos" and so the word "casino" itself is of Italian origin.

In Italy today there are only 4 casinos regulated by their respective municipal authorities, dating back to the 1930's, when an ad hoc regulatory regime was introduced by the Mussolini-era government which granted them a unique and special status as "fully-licensed gambling houses" (Mancini \& Tonucci \& Partners, 2016).

$\mathrm{ADM}$ regulates gaming machines and sets out an inventory of machines available to players in bars, tobacco shops, shopping malls and gaming parlours. There are some 397,000 machines, which are connected to the ADM network.

In 2006, the liberalization of the Italian online gambling market gradually began after the complaint was received in 2003 by the European Commission, which investigated the case and started infringement proceedings against Italy. As a consequence, Italy was the first EU member state to legalize, license and regulate online gambling in a comprehensive way.

There are two market segments for public (legal) gaming in Italy, managed by two bodies such as the Autonomous Administration of State Monopolies (AAMS) and the other represented by the casinos, formed into a joint-stock company held by the licensees, i.e. the municipalities, regions and provinces (de Felice \& Martucci, 2017).

In 2016 (Table 4, Figure $2-4$ ) there was an increase of $8 \%$ in expenditure (equivalent to 7 billion EUR) in comparison to 2015 (88 billion), which is a total of gambling spending at 95 billion EUR (Friolo, 2017). There was no investment in the new or existing casinos in Italy since 2000, but they set up a new network of gaming salons with VLT.

From 2001 to 2016, there is constant growh (index 6.64).

Average share of Gambling and betting activities in GDP (in the period 2001 - 2016) is $3.37 \%$, i.e. in terms of the growth index (base in 2001) in 2017 a coefficient 5.08 is realized. While the number of gambling companies remains unchanged, the number of employees has increased 3 times.

In government report released in October of 2015, it was indicated that in Italy there were around 1.3 million problem gamblers per 60 million inhabitants, with only 12,000 receiving treatment for their addiction (Washington, 2016). The island of Capri in 2016 became the first place to ban 
slots from "inappropriate' areas" such as the vicinity of schools, churches, tourist beaches, and cash machines. Italy ranks first in the European market for online gaming (de Felice \& Martucci, 2017). That means that the Italian market is the main regulated gambling market in Europe and the fourth in world in terms of gross gambling revenue (Calvosa, 2017, 17).

Table 4. Italy Revenue from gambling and betting and GDP (million EUR)

\begin{tabular}{|c|c|c|c|c|c|}
\hline Year & $\begin{array}{l}\text { Revenue from } \\
\text { gambling and } \\
\text { betting }\end{array}$ & GDP & $\begin{array}{l}\text { Gambling and } \\
\text { betting in GDP }\end{array}$ & $\begin{array}{l}\text { Basic gambling } \\
\text { Income Index } \\
(2001)\end{array}$ & $\begin{array}{c}\text { Basic index } \\
\text { of gambling } \\
\text { revenues in GDP } \\
(2001)\end{array}$ \\
\hline 2001 & 14,515 & $1,298,890$ & $1.12 \%$ & 1.00 & 1.00 \\
\hline 2002 & 15,600 & $1,345,794$ & $1.16 \%$ & 1.07 & 1.04 \\
\hline 2003 & 15,492 & $1,390,710$ & $1.11 \%$ & 1.07 & 1.00 \\
\hline 2004 & 24,786 & $1,448,363$ & $1.71 \%$ & 1.71 & 1.53 \\
\hline 2005 & 28,487 & $1,489,726$ & $1.91 \%$ & 1.96 & 1.71 \\
\hline 2006 & 35,243 & $1,548,473$ & $2.28 \%$ & 2.43 & 2.04 \\
\hline 2007 & 42,193 & $1,609,551$ & $2.62 \%$ & 2.91 & 2.35 \\
\hline 2008 & 47,554 & $1,632,151$ & $2.91 \%$ & 3.28 & 2.61 \\
\hline 2009 & 54,410 & $1,572,878$ & $3.46 \%$ & 3.75 & 3.10 \\
\hline 2010 & 61,400 & $1,604,515$ & $3.83 \%$ & 4.23 & 3.42 \\
\hline 2011 & 79,900 & $1,637,463$ & $4.88 \%$ & 5.50 & 4.37 \\
\hline 2012 & 88,600 & $1,613,265$ & $5.49 \%$ & 6.10 & 4.91 \\
\hline 2013 & 84,600 & $1,604,599$ & $5.27 \%$ & 5.83 & 4.72 \\
\hline 2014 & 84,500 & $1,621,827$ & $5.21 \%$ & 5.82 & 4.66 \\
\hline 2015 & 88,200 & $1,645,439$ & $5.36 \%$ & 6.08 & 4.80 \\
\hline 2016 & 95,000 & $1,672,438$ & $5.68 \%$ & 6.54 & 5.08 \\
\hline Average & 53,780 & $1,546,005$ & $3.38 \%$ & & \\
\hline
\end{tabular}

Source: (“Agenzia Delle Dogane E Dei Monopoli” 2017; own research)

Consumption of gambling is in constant growth. The biggest increases are in betting and VLT salons (Agenzia delle dogane e dei Monopoli, 2017). Casino, Lottery, Slot club and Online are more domestic oriented.

\section{SLOVENIA}

According to Luin (Luin, 2004), the first casino in what is now Slovenia was opened 1913 in Portorož on the Slovenian coast. During the time of the Yugoslavian Monarchy system, casino gambling was prohibited just as it was in the other European countries at that time (Makarović, Macur, \& Rončević, 2011). After second World War, in The Federal People's Republic of Yugoslavia lottery gambling was allowed only for the purpose of humanitarian and cultural benefit on the approval of Ministry of Finance, in accordance with the act in 1946 (Ibid).

There are three distinctive periods in the gambling regulation of Slovenia and former Yugoslavia. In the first period, in 1965, the Socialist Federal Republic of Yugoslavia allowed all the constituent republics to regulate gambling by their own legislative instruments. In Slovenia ("socialist republic" within the Yugoslav federation) the law about "special games" was brought out that also included casino gambling. This law allowed casino gambling for foreign tourists only and with games played in a foreign currency (USD, DEM, ITL).

The first Slovenian casino was opened (as an experiment) in Portorož in 1964. Although the law strictly prohibited foreign companies from participating, Casino San Remo actually cooperated in the management of the casino in Portorož up until 1969. Politicians were knowingly tolerating the 
obvious violation of the law, since the foreign partner had assisted the casino's start-up. A casino in Bled, Slovenia's most renowned Alpine resort, was opened in 1965. Ljubljana was another city that met the criteria in terms of the hotel rooms and so a casino was opened there in 1969, but was closed shortly thereafter due to irregularities (Hojnik \& Luin, 2016).

In the second period, in the 1980s, this law changed to some extent which meant that casino gambling became the main attraction in some tourist destinations, such as Nova Gorica, through the shift toward an "American" concept of casino gambling (Makarović, Macur, \& Rončević, 2011). In the third period, after the 1990s, casino gambling became more liberalized since prohibition for Slovenian citizens to play in the casino was abolished in 1995. A new system of concession contracts between the state and the providers of gambling services was established (Luin, 2004). "Gambling halls" (smaller casinos equipped with slot machines) became more common and accessible to the local Slovenian population. Since the adoption in 1995 the actual systemic legislation was later amended in 2001, 2003, 2010, and 2012. In 2015, the new legislative proposals allowed further liberalization.

There are two types of gambling according to the Slovenian legislation: the "classical" gambling and casino gambling. "Classic gambling" includes lotteries, lotteries with instant prizes, quiz lotteries, bingo, lotto, sports betting, sports pools, raffles and other similar games. There are two operators which administrate the "classic games": Loterija Slovenije (The Lottery of Slovenia), that runs eight different series of games and Športna loterija (The Sports Lottery), which runs six games. Games such as lotteries, bingo and raffles can be organized occasionally by humanitarian and non-profit associations (Makarović et al., 2011).

Additionally, the law defined two places where special gambling can be organized: casinos and gambling halls. The government, by the law, could award concessions for up to 15 casinos and up to 45 gambling halls. A great increase was recorded (+47\%), between 2002 and 2007 in the number of gambling halls due to legislative liberalization in 2001 and 2003 (Zagoršek, Jaklič, \& Zorič, 2007), when the number rose to 13 casinos and 34 gaming rooms. Later on, a decline began and so currently there are 10 casinos and 26 gaming halls (Republika Slovenija Ministrstvo za finance 2017).

Important restrictions in Slovenian legislation concerning gambling are the age restriction, such as Article 83 of Gambling Act which defined that those younger than 18 years are not allowed to engage in casino-style gambling and they are also prohibited from entering the casino. For other types of gambling there are no age restrictions.

In the period from 2001 to 2016 (Table 5, Figure 2 - 4), there is a low growth (index 1.09). Average share of gambling and betting activities in the GDP (in the period 2001 - 2015) is $1.04 \%$, i.e. in terms of the growth index (base in 2001) in 2017 a 0.64 coefficient is realized. The number of gambling companies and the number of employees remains at the same level as ten years ago.

Casinos and Slot clubs in larger tourist and border areas are more tourist/foreign-oriented (Italy) and Lottery and Online gambling are more domestic oriented. 
Table 5. Slovenia Revenue from gambling and betting and GDP (million EUR)

\begin{tabular}{|c|c|c|c|c|c|c|c|}
\hline Year & $\begin{array}{c}\text { Number of } \\
\text { company }\end{array}$ & Employees & $\begin{array}{c}\text { Revenue } \\
\text { from } \\
\text { gambling } \\
\text { and betting }\end{array}$ & GDP & $\begin{array}{l}\text { Gambling } \\
\text { and betting } \\
\text { in GDP }\end{array}$ & $\begin{array}{c}\text { Basic } \\
\text { gambling } \\
\text { Income } \\
\text { Index } \\
(2001)\end{array}$ & $\begin{array}{l}\text { Basic index } \\
\text { of gambling } \\
\text { revenues in } \\
\text { GDP (2001) }\end{array}$ \\
\hline 2001 & & 1,908 & 281 & 23,333 & $1.20 \%$ & 1.00 & 1.00 \\
\hline 2002 & & 1,913 & 289 & 25,023 & $1.16 \%$ & 1.03 & 0.96 \\
\hline 2003 & & 1,991 & 284 & 26,319 & $1.08 \%$ & 1.01 & 0.90 \\
\hline 2004 & 47 & 2,182 & 338 & 27,763 & $1.22 \%$ & 1.20 & 1.01 \\
\hline 2005 & 48 & 2,375 & 369 & 29,227 & $1.26 \%$ & 1.32 & 1.05 \\
\hline 2006 & 45 & 2,474 & 400 & 31,561 & $1.27 \%$ & 1.42 & 1.05 \\
\hline 2007 & 49 & 2,840 & 417 & 35,153 & $1.19 \%$ & 1.49 & 0.99 \\
\hline 2008 & 52 & 2,860 & 418 & 37,951 & $1.10 \%$ & 1.49 & 0.92 \\
\hline 2009 & 55 & 2,800 & 392 & 36,166 & $1.08 \%$ & 1.40 & 0.90 \\
\hline 2010 & 57 & 2,526 & 363 & 36,252 & $1.00 \%$ & 1.29 & 0.83 \\
\hline 2011 & 55 & 2,407 & 360 & 36,896 & $0.97 \%$ & 1.28 & 0.81 \\
\hline 2012 & 54 & 2,263 & 340 & 35,988 & $0.94 \%$ & 1.21 & 0.79 \\
\hline 2013 & 48 & 2,155 & 309 & 35,907 & $0.86 \%$ & 1.10 & 0.72 \\
\hline 2014 & 51 & 2,123 & 295 & 37,303 & $0.79 \%$ & 1.05 & 0.66 \\
\hline 2015 & 48 & 2,154 & 303 & 38,543 & $0.78 \%$ & 1.08 & 0.65 \\
\hline 2016 & 46 & 2,299 & 306 & 39,769 & $0.77 \%$ & 1.09 & 0.64 \\
\hline Average & 50 & 2,329 & 341 & 33,322 & $1.04 \%$ & & \\
\hline
\end{tabular}

Source: (Republic of Slovenia Statistical Office 2017; own research)

\section{METHODOLOGY}

In this paper we have followed the following methodology. It includes three steps as shown (Figure $1)$ :

Figure 1. Research methodology

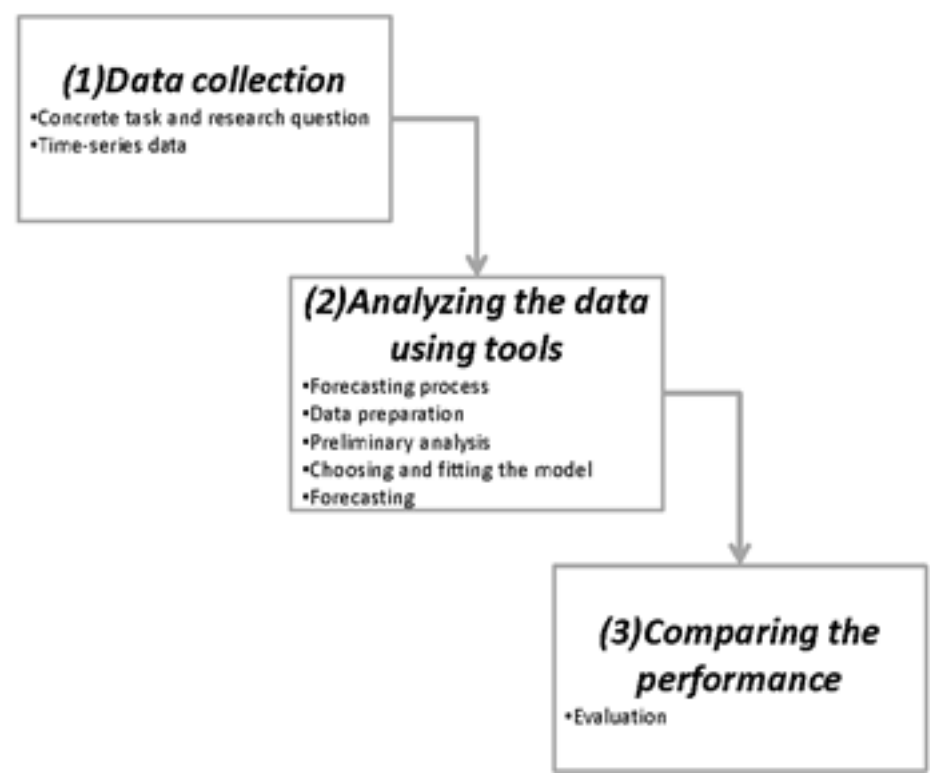




\section{DATA COLLECTION}

For the purpose of this research, the data on the examined countries was collected from the national statistical offices or national gambling supervisory offices. For the rest of the world we have used data from the $\mathrm{H} 2$ gambling capital and World Bank. The main reason in using these sources is intention to observe the total revenue in gambling industry which is important for our discussion.

\section{CONCRETE TASK AND RESEARCH QUESTION}

The task to be solved in this paper is to analyze the dataset that is the revenue of gambling within sixteen years (from 2001 to 2016) in order to find some patterns, cyclical or seasonal features or other significant information that allows forecasting of the future consumption within the certain degree of accuracy. The main research question is How important is gambling for the involved countries and what proportion of the national GDP does the gambling revenue account for?

\section{TIME-SERIES DATA}

The dataset represents the consumption from gambling and GDP with a one-year sampling rate over a period of sixteen years. The data presents different quantities and some sub-metering values and is a typical representative of a time-series data that can be defined as a sequence of observed values. One of the most distinctive features of the time-series is that data is not generated independently; their dispersion varies in time, and in often governed by a trend and has cyclic components. An observed time series can be decomposed into three components: the trend (long term direction), the seasonal (systematic, calendar related movements) and the irregular (unsystematic, short term fluctuations) (Beliaeva, Petrochenkov, \& Bade, 2013).

\section{ANALYZING THE DATA USING TOOLS}

This is the second step of our methodology. The datasets are analyzed using the software Tableau 10.4 .

\section{FORECASTING PROCESS}

Forecasting is a process of estimating the unknown. It can be defined as the science of predicting future outcomes. Forecast should be fitted with the following characteristics: it should be timely, it should be as accurate as possible; it should be reliable; it should be in meaningful units. In order to do the forecasting process the following steps should be computed (Nolan (1994; Armstrong (2001)):

1. Definition of the purpose of the forecasting;

2. Data preparation;

3. Preliminary analysis;

4. Choosing and fitting the best model;

5. Forecasting;

6. Evaluation.

\section{DATA PREPARATION}

To analyze the consumption of gambling and its share in GDP in selected countries the following attributes are required: Year, Revenue from gambling and betting, GDP. We calculated: Gambling and betting in GDP; Basic Gambling Income Index (2001); Basic index of gambling revenues in GDP (2001), for all observed years.

\section{PRELIMINARY ANALYSIS}

The good way to understand the data is visualization in order to find some consistent patterns or significant trends. With the help of Tableau 10.4, a powerful statistical tool for exploration and visualization of the datasets, the graphs for the different time periods are constructed (Tableau, 2014).

\section{CHOOSING AND FITTING THE MODEL}

The next step is to determine the appropriate model that fits the data. For that purpose we use Box and Jenkins approach (Box, Jenkins, Reinsel, \& Ljung, 2015) that allows selecting from a group of forecasting models the one that is the best to fit the time series data. The ARIMA (autoregressive integrated moving average) modelling can be applied to the most types of time series data. The 
forecasting accuracy of ARIMA model is considered by the scientists to be of a high degreel.

\section{FORECASTING}

The forecasting is done for the period from 2017 to 2027 . The results of the prediction with respect to year's period are presented in the figure $2-4$.

$$
\begin{gathered}
\text { Equation 1 Forecasting } \\
\hat{y}_{t+h \mid t}=\ell_{t}+s_{t-m+h_{m}^{+}} \\
\ell_{t}=\alpha\left(y_{t}-s_{t-m}\right)+(1-\alpha) \ell_{t-1} \\
s_{t}=\gamma\left(y_{t}-\ell_{t-1}\right)+(1-\gamma) s_{t-m}
\end{gathered}
$$

\section{COMPARING THE PERFORMANCE}

This is the last and final step of the proposed methodology. We have given the screenshots obtained at the time of analyzing the dataset.

\section{EVALUATION}

Evaluation was made by using the Mean absolute scaled error (MASE) which is the most reliable according to Hyndman and Koehler (table 6).

If the MASE is lower than 1 the forecast model is right (Hyndman \& Koehler, 2006). In the table 6 you will see that in all cases MASE is lower than 1. On the other side, Akaike information criterion (AIC) is very low which means the used model is appropriate (Bozdogan, 1987).

These results represent the high accuracy of the forecast. This proves the assurance of scientists that

\begin{tabular}{|c|c|c|c|c|c|c|c|c|c|c|}
\hline \multicolumn{11}{|c|}{ Sum of Austria (Gambling in GDP index) } \\
\hline \multicolumn{3}{|l|}{ Model } & \multicolumn{5}{|c|}{ Quality Metrics } & \multicolumn{3}{|c|}{ Smoothing Coefficients } \\
\hline Level & Trend & Season & RMSE & MAE & MASE & MAPE & AIC & Alpha & Beta & Gamma \\
\hline Additive & Additive & None & 0.057 & 0.046 & 0.97 & $5.7 \%$ & -82 & 0.500 & 0.000 & 0.000 \\
\hline \multicolumn{11}{|c|}{ Sum of Croatia (Gambling in GDP index) } \\
\hline \multicolumn{3}{|l|}{ Model } & \multicolumn{5}{|c|}{ Quality Metrics } & \multicolumn{3}{|c|}{ Smoothing Coefficients } \\
\hline Level & Trend & Season & RMSE & MAE & MASE & MAPE & AIC & Alpha & Beta & Gamma \\
\hline Additive & Additive & None & 0.318 & 0.261 & 0.76 & $16.1 \%$ & -27 & 0.100 & 0.500 & 0.000 \\
\hline \multicolumn{11}{|c|}{ Sum of Italy (Gambling in GDP index) } \\
\hline \multicolumn{3}{|l|}{ Model } & \multicolumn{5}{|c|}{ Quality Metrics } & \multicolumn{3}{|c|}{ Smoothing Coefficients } \\
\hline Level & Trend & Season & RMSE & MAE & MASE & MAPE & AIC & Alpha & Beta & Gamma \\
\hline Additive & Additive & None & 0.358 & 0.273 & 0.88 & $13.1 \%$ & -23 & 0.500 & 0.000 & 0.000 \\
\hline \multicolumn{11}{|c|}{ Sum of Slovenia (Gambling in GDP index) } \\
\hline \multicolumn{3}{|l|}{ Model } & \multicolumn{5}{|c|}{ Quality Metrics } & \multicolumn{3}{|c|}{ Smoothing Coefficients } \\
\hline Level & Trend & Season & RMSE & MAE & MASE & MAPE & AIC & Alpha & Beta & Gamma \\
\hline Additive & Additive & None & 0.058 & 0.045 & 0.63 & $5.0 \%$ & -81 & 0.500 & 0.000 & 0.000 \\
\hline \multicolumn{11}{|c|}{ Sum of the World (Gambling in GDP index) } \\
\hline \multicolumn{3}{|l|}{ Model } & \multicolumn{5}{|c|}{ Quality Metrics } & \multicolumn{3}{|c|}{ Smoothing Coefficients } \\
\hline Level & Trend & Season & RMSE & MAE & MASE & MAPE & AIC & Alpha & Beta & Gamma \\
\hline Additive & Additive & None & 0.030 & 0.026 & 0.78 & $2.7 \%$ & -103 & 0.500 & 0.000 & 0.000 \\
\hline
\end{tabular}
forecasting accuracy of ARIMA model is normally of a high degree.

All forecasts were computed using exponential smoothing.

Table 6. Forecast error measures

Source: (Tableau output; own research)

\footnotetext{
${ }^{1}$ (Beliaeva et al., 2013)
} 


\section{RESULTS}

The data processed by the machine learning algorithm provides efficient results that can be understood but the obtained information is too large and the conclusions can prove to be difficult to make. It is well known that a visual representation is worth a thousand words. Hence this information can be easily understood by the Tableau's interactive data visualization focused on business intelligence. Tableau helps in interactive data visualization of products.

According to collected data we could present and compare the revenues from gambling, share of revenues in GDP and gambling revenue index in observed countries.

Gambling revenue is presented in figure 2 and Gambling revenue index in figure 3. The absolute highest growth is recorded in Italy. Croatia also has a lot of growth. The Austrian market is stable. Slovenian even shows signs of regression. With 90\% confidence it can be predicted that in 2027 there will be a 626,230 billion USD gambling revenue (index from 2001 to 2027 is 2.8). Italy can expect 154,661 million EUR (index 10.6), Austria 1,806 million EUR (index 1.5), Croatia, 505 million (index 5.7). EUR and Slovenia 327 million EUR (index 1.2).

Figure 2. Gambling revenue (2001 - 2027)
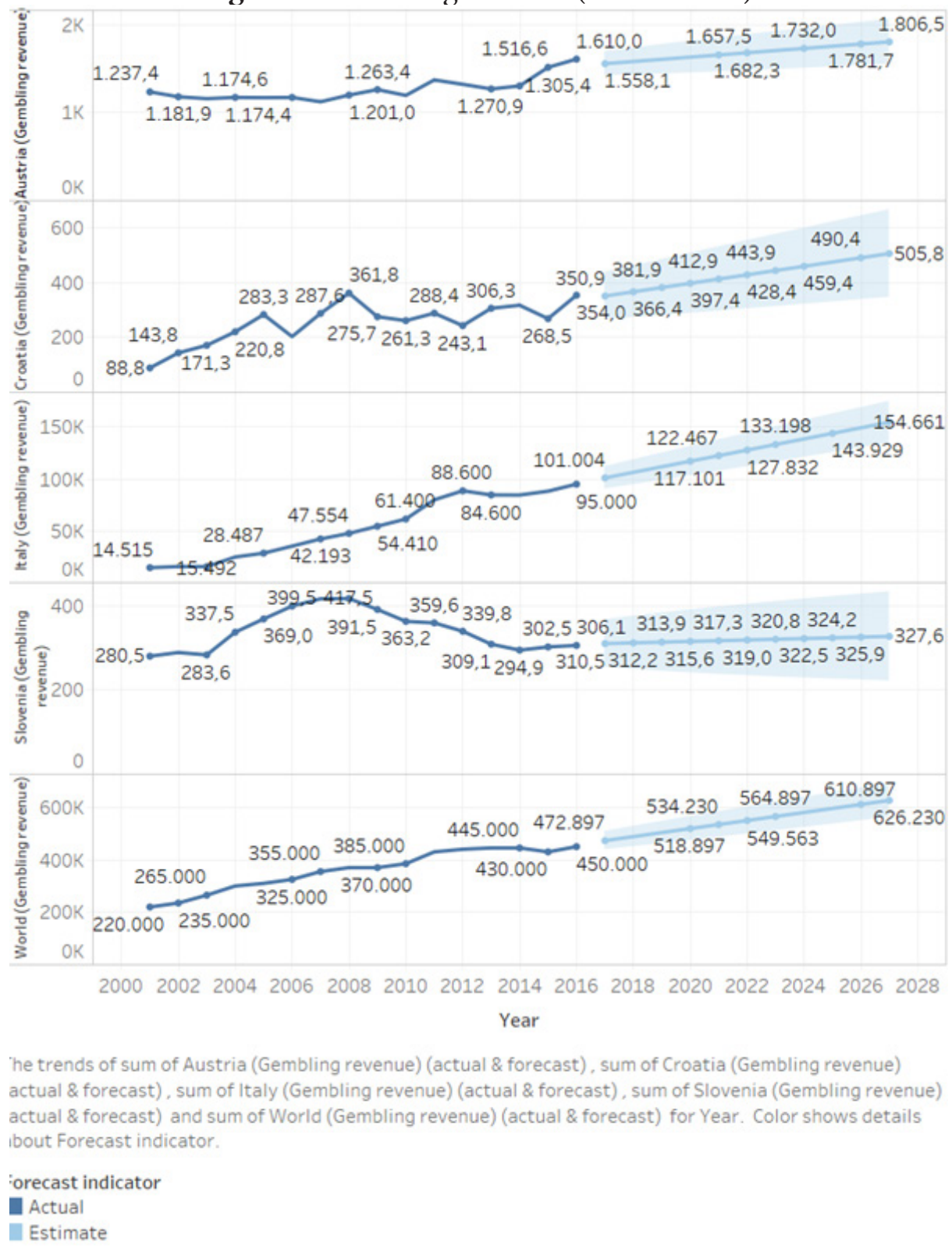

Source: ( ("H2 Gambling Capital” 2017; "BMF - Bundesministerium Für Finanzen” 2017; “The World’s Biggest Gamblers” 2017; “Agenzia Delle Dogane E Dei Monopoli” 2017; Republic of Slovenia Statistical Office 2017; Republic of Croatia Croatian Bureau of Statistics 2017; own research) 
Using gambling revenue index in observed period the strongest growth can be seen in Italy and Croatia. The growth in Austria and Slovenia are below the world average. This points to a downturn in the gambling market. In Slovenia, this is due to non-involvement in gambling services, especially in online gambling.

Figure 3. Gambling revenue (index 2001 - 2027)

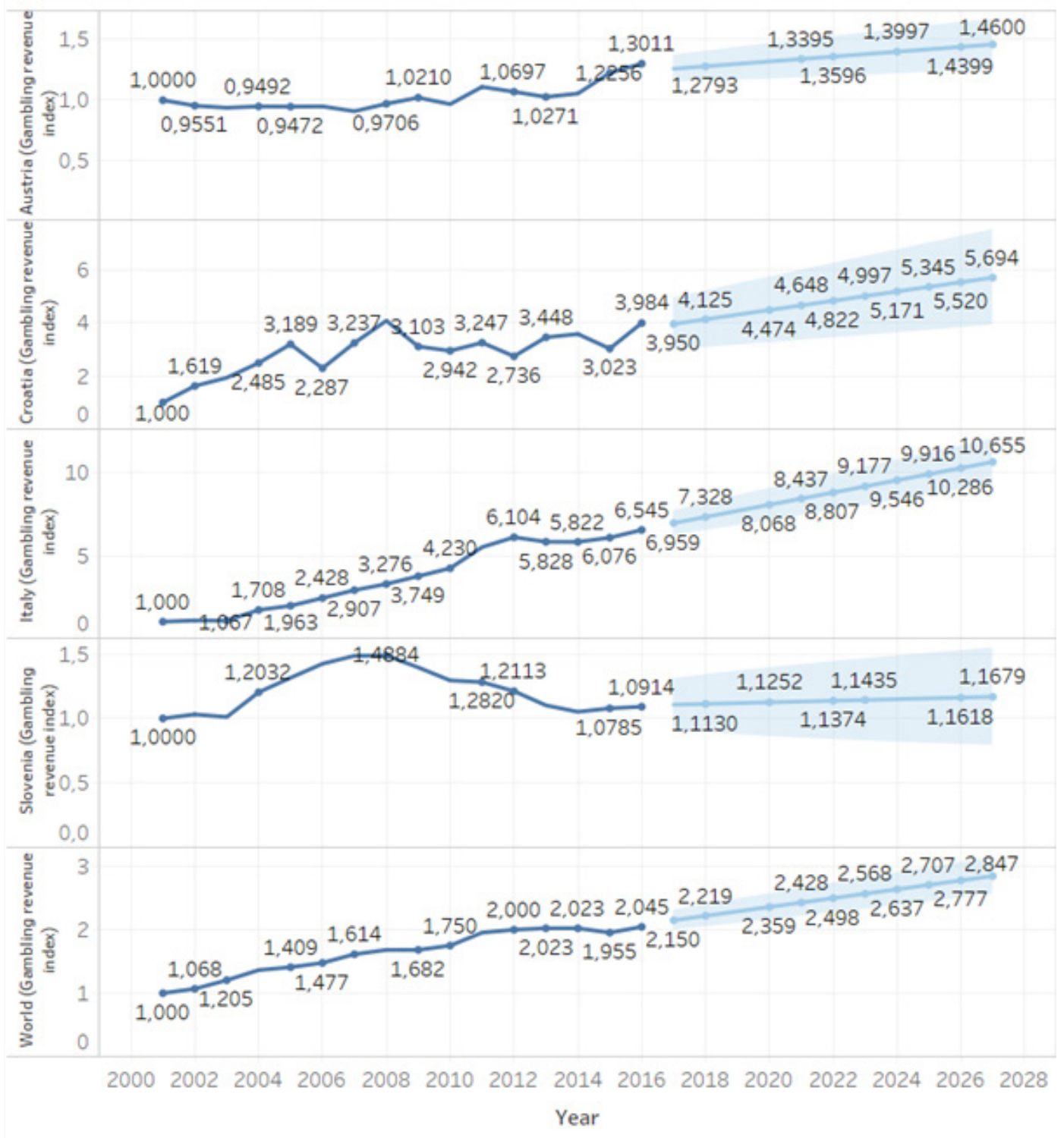

The trends of sum of Austria (Gambling revenue index) (actual \& forecast), sum of Croatia (Gambling revenue index) (actual \& forecast), sum of Italy (Gambling revenue index) (actual \& forecast), sum of Slovenia (Gambling revenue index) (actual \& forecast) and sum of World (Gambling revenue index) (actual \& forecast) for Year. Color shows details about Forecast indicator.

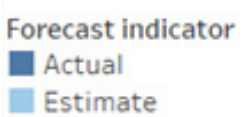

Source: ( ("H2 Gambling Capital” 2017; "BMF - Bundesministerium Für Finanzen” 2017; “The World’s Biggest Gamblers" 2017; "Agenzia Delle Dogane E Dei Monopoli” 2017; Republic of Slovenia Statistical Office 2017; Republic of Croatia Croatian Bureau of Statistics 2017; own research)

Next, in figure 4 the share of gambling revenue in GDP is presented. As we can see there is a stable index in Croatia, Austria and the world. In Italy it is very progressive (in 2016 is 5 times more than 2001). In Slovenia it was progressive till 2006 and regressive after that year. 
Figure 4. Gambling in GDP (index 2001 - 2027)

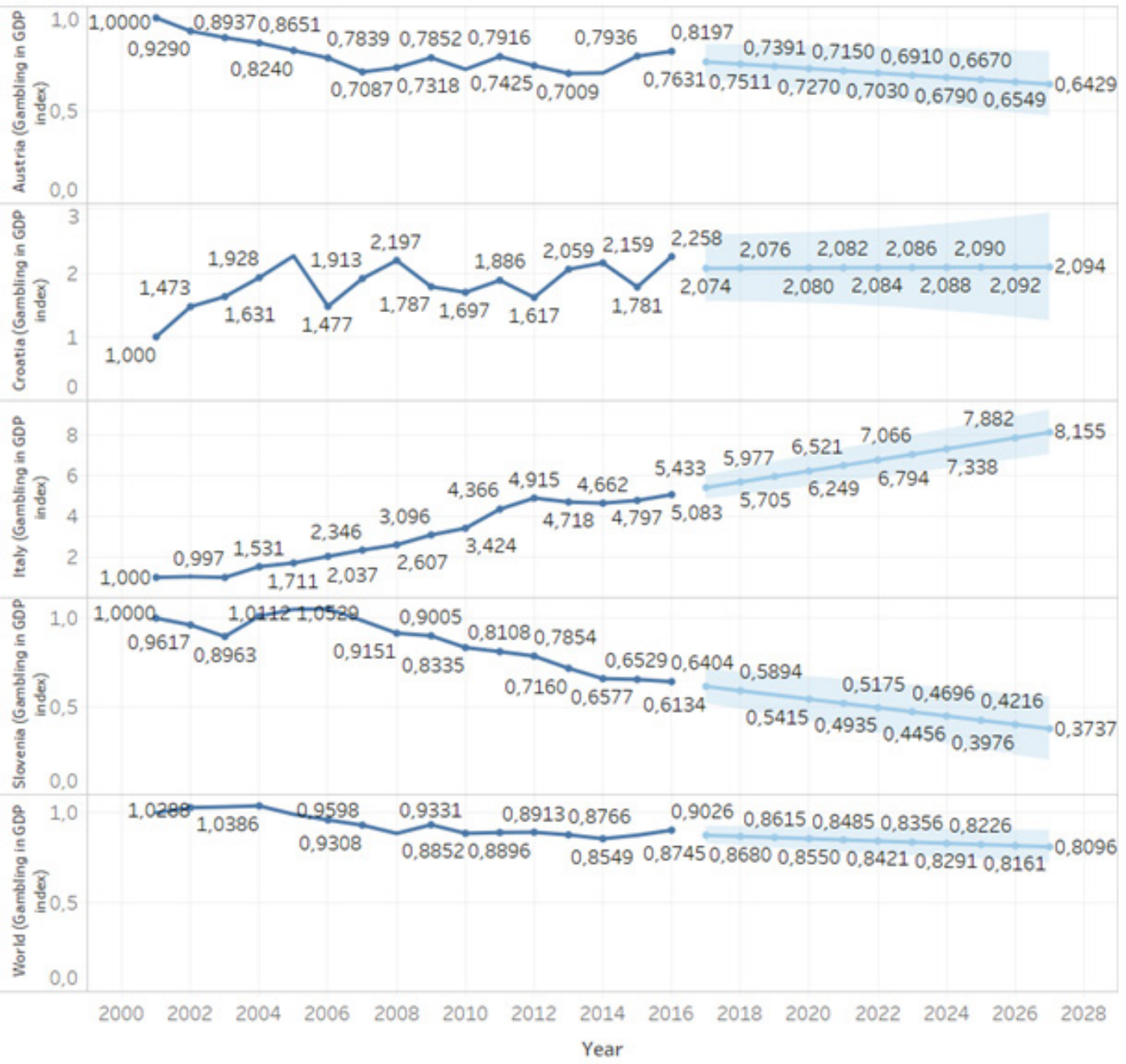

The trends of sum of Austria (Gambling in GDP index) (actual \& forecast), sum of Croatia (Gambling in GDP index) (actual \& forecast), sum of Italy (Gambling in GDP index) (actual \& forecast), sum of Slovenia (Gambling in GDP index) (actual \& forecast) and sum of World (Gambling in GDP index) (actual \& forecast) for Year. Color shows details about Forecast indicator.

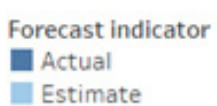

Source: ( (“H2 Gambling Capital” 2017; “BMF - Bundesministerium Für Finanzen” 2017; “The World’s Biggest Gamblers” 2017; “Agenzia Delle Dogane E Dei Monopoli” 2017; Republic of Slovenia Statistical Office 2017; Republic of Croatia Croatian Bureau of Statistics 2017; own research)

Globally the gambling consumption is expected to decline. The trend is mostly in line with Slovenia's prediction, while Austria will maintain the level of the world average. However, Croatia and above all Italy will increasingly depend on gambling revenues.

The latest comparison is the placement with regard to the players' orientation (Table 7). Austria, Croatia and Slovenia were in the past foreign (F) oriented casino destinations. Nowadays however with online and gambling halls mostly locally (L) oriented. 
Table 7. Orientation of gambling

\begin{tabular}{|c|c|c|c|c|c|}
\hline & & Croatia & Austria & Italy & Slovenia \\
\hline \multirow{8}{*}{$\begin{array}{l}\text { Land-based } \\
\text { Casinos }\end{array}$} & $\begin{array}{c}\text { Betting Shops/ } \\
\text { Off Track } \\
\text { Betting }\end{array}$ & $\mathrm{L}$ & $\mathrm{L}$ & $\mathrm{L}$ & $\mathrm{L}$ \\
\hline & Bingo & $\mathrm{L}$ & $\mathrm{L}$ & $\mathrm{L}$ & $\mathrm{L} / \mathrm{F}$ \\
\hline & $\begin{array}{l}\text { Card Rooms/ } \\
\text { Poker }\end{array}$ & $\mathrm{L}$ & $\mathrm{L}$ & $\mathrm{L}$ & $\mathrm{L} / \mathrm{F}$ \\
\hline & Casinos & $\mathrm{F}$ & $\mathrm{L} / \mathrm{F}$ & $\mathrm{L}$ & $\mathrm{F}$ \\
\hline & Lotteries & $\mathrm{L}$ & $\mathrm{L}$ & $\mathrm{L}$ & $\mathrm{L}$ \\
\hline & Racing & $\mathrm{L}$ & $\mathrm{L}$ & $\mathrm{L}$ & $\mathrm{L}$ \\
\hline & Slot Machines & $\mathrm{L}$ & $\mathrm{L}$ & $\mathrm{L}$ & $\mathrm{L} / \mathrm{F}$ \\
\hline & $\begin{array}{l}\text { Tribal Gaming } \\
\text { (only in USA) }\end{array}$ & & & & \\
\hline \multirow{6}{*}{ Online Casinos } & Online Betting & $\mathrm{L}$ & $\mathrm{L}$ & $\mathrm{L}$ & $\mathrm{L}$ \\
\hline & Online Bingo & $\mathrm{L}$ & $\mathrm{L}$ & $\mathrm{L}$ & $\mathrm{L}$ \\
\hline & Online Casino & $\mathrm{L} / \mathrm{F}$ & $\mathrm{L} / \mathrm{F}$ & $\mathrm{L}$ & $\mathrm{L}$ \\
\hline & $\begin{array}{c}\text { Online } \\
\text { Lotteries }\end{array}$ & $\mathrm{L}$ & $\mathrm{L}$ & $\mathrm{L}$ & $\mathrm{L}$ \\
\hline & Online Poker & $\mathrm{L}$ & $\mathrm{L}$ & $\mathrm{L}$ & $\mathrm{L}$ \\
\hline & $\begin{array}{c}\text { Online Racing/ } \\
\text { Advance- } \\
\text { Deposit } \\
\text { Wagering }\end{array}$ & $\mathrm{L}$ & $\mathrm{L}$ & $\mathrm{L}$ & $\mathrm{L}$ \\
\hline
\end{tabular}

Source: (own research)

Each country needs to find the most suitable business model. In any case, the Internet gambling needs to be included considering the national needs. Especially when it comes to the protection of citizens. 


\section{CONCLUSION}

The purpose of this review article has been to expose the gambling situation in Austria, Croatia, Italy and Slovenia. Based on the historical perspective we have reviewed the evolution in last 16 years and forecasts by the year 2027. It is worth noting that the gaming sector has suffered a significant recession in the last few years owing to the severe economic crisis in 2007.

The main research question is How important is gambling for the involved countries and what proportion of the national GDP does the gambling revenue account for? As we can see (table $1-5$ and figure 2-4) Italy is becoming increasingly dependent on gambling revenues because its share in GDP is 5.7 \%. The reason for this is the liberalization of VLT salons and Online gambling. Online gambling is present on the global market in many ways which have already overtaken the prime roll from physical casinos. Most people today prefer the comfort of making wagers from their home, and punters can find nearly every kind of gambling from internet casinos to online lotteries (Oldroyd, 2017).

While the importance remains stable at the World level and in Austria, it is increasing in Croatia and decreasing in Slovenia. The pattern shown here is that the share of gambling revenues in GDP is increasing in those countries where the gambling is locally oriented.

Gaming revenues in GDP should not be neglected, but we must not rely on them because they represent too great a risk. The local population consumption of gaming increases the likelihood of gambling addiction. The gambling was and will be present in the future too. The activity itself does not contribute to the national income, but brings the redistribution. Therefore it would make sense to keep the gambling of the country under control. Countries invest in development only if the gambling is export oriented.

Business forecast helps governmental sector and gaming operators to visualize the big picture by forecasting the revenue to get a general idea of the coming years. If any changes are needed then those changes are done with the objective of achieving a more profitable success. The results of the research can be applied in different fields. For example, knowing the revenue from gambling and betting is of great importance for several reasons. First of all, the governmental sector can calculate the share in GDP and the revenue from taxes which will get into the state budget. Secondly, analysing the data of Gambling revenues is useful for companies (gaming operators) for predicting probable future consumption to plan the technological cycles and budget costs.

Based on the results of the analysis and discussion, it could be noted that the research question is well chosen and represents the main problem exposed in this paper.

\section{LIMITATIONS AND FUTURE RESEARCH DIRECTIONS}

The paper has certain acknowledgeable limitations and offers some directions for future research. Lack of certain data points to a limited scope of our analysis which prevents presenting detailed findings. All data was collected from secondary sources with all limitations in that sense.

There were no prior research studies on this topic which means some findings couldn't be compared with similar ones to find out whether there are inconsistencies.

This study, as applicative research, defines some of the opportunities for future research in terms of the new aspect concerning the subject.

It would be interesting to observe some economic impact of gambling on observed countries' economies in a few categories such as investment, employment and foreign trade.

Acknowledgments: This paper is a result of a bilateral project between Montenegro and Slovenia: Joint experience of the development of casino business in a tourist destination - Montenegro and Slovenia.

Funding: None.

Author Contributions: Andrej Raspor prepared the concept of the paper, designed thw survey and methodology, did statistical analysis and wrote results and discussion. Darko Lacmanović conducted the survey, collected data, wrote literature review. Iva Bulatović and Ana Stranjančević wrote the conclusion, introduction, abstract and literature. Compliance with Ethical Standards

Conflict of interest: The authors declare no conflict of interest. 


\section{REFERENCES}

[1]Agenzia delle dogane e dei Monopoli. (2017). Agenzia delle dogane e dei Monopoli. Retrieved 8 September 2017, from https://www.agenziadoganemonopoli.gov.it/portale/it/web/guest/home

[2gArmstrong, J. S. (2001). Principles of forecasting: a handbook for researchers and practitioners (Vol. 30). Springer Science \& Business Media.

[3]Beliaeva, N., Petrochenkov, A., \& Bade, K. (2013). Data set analysis of electric power consumption. European Researcher. Series A, (10-2), 2482.

[4]Bloomberg. (2016). Bloomberg Industry Market Leaders.

[5]BMF - Bundesministerium für Finanzen. (2017). Retrieved 8 September 2017, from https://www. bmf.gv.at/

[6]Bolen, D. W., \& Boyd, W. H. (1968). Gambling and the gambler: A review and preliminary findings. Archives of General Psychiatry, 18(5), 617-630.

[7]Bozdogan, H. (1987). Model selection and Akaike's information criterion (AIC): The general theory and its analytical extensions. Psychometrika, 52(3), 345-370.

[8]Cabot, A. N., Thompson, W. N., Tottenham, A., \& Braunlich, C. G. (1999). International casino law (3rd ed.). Reno, NV: College of Business Administration University of Institute for the study of gambling and commercial gaming.

[9]Calvosa, P. (2017). Responsible Gambling Strategies for Internet Gambling: An Empirical Investigation into the Italian Gambling Market. International Journal of Business and Management, 12(7), 17.

[10]Cotte, J., \& Latour, K. A. (2008). Blackjack in the kitchen: Understanding online versus casino gambling. Journal of Consumer Research, 35(5), 742-758.

[11gde Felice, A., \& Martucci, I. (2017). Gambling as a Restraint to the Italian Economy. Advances in Management and Applied Economics, 7(1), 73-87.

[12]Fontenot, C. (2016). Top 10 Sites: Largest Online Gambling Companies 2016. Retrieved 7 September 2017, from http://www.grizzlygambling.com/articles/top-ten-largest-online-gamblingcompanies-2016.html

[13]Friolo, G. (2017). Gioco d'azzardo: anno record in Italia, spesi 95 miliardi | documentazione.info. Retrieved 8 September 2017, from http://www.documentazione.info/gioco-dazzardo-anno-recordin-italia-spesi-95-miliardi

[14]Gainsbury, S. M., Russell, A., Hing, N., Wood, R., Lubman, D., \& Blaszczynski, A. (2015). How the Internet is changing gambling: Findings from an Australian prevalence survey. Journal of Gambling Studies, 31(1), 1-15.

[15]Glücksspiel \&amp; Sportwetten in Österreich $2017 \mid$ BRANCHENRADAR ${ }^{\circledast}$. (2017). Retrieved 15 October 2017, from https://www.branchenradar.com/Artikel.aspx?id=50

[16]Griffiths, M. (2017). The psychosocial impact of gambling in virtual reality. Casino \& Gaming International, (29), 51-54.

[17]Griffiths, M., Parke, A., Wood, R., \& Parke, J. (2006). Internet gambling: An overview of psychosocial impacts. UNLV Gaming Research \& Review Journal, 10(1), 27-39.

[18]H2 Gambling Capital. (2017). Retrieved 8 September 2017, from http://h2gc.com/

[19]Hojnik, J., \& Luin, D. (2016). Gambling Regulation in Slovenia: From Adapting to Socialist Morality up to EU Free Trade Environment.

[20]Horváth, C., \& Paap, R. (2012). The effect of recessions on gambling expenditures. Journal of Gambling Studies, 28(4), 703-717. http://doi.org/https://doi.org/10.1007/s10899-011-9282-9

[21]Hrvatska Lutrija. (2017).

[22]Krogulecki, D. (2017). Senate Fiscal Agency.

[23]Kuss, D. J., \& Griffiths, M. (2012). Internet gambling addiction. In Encyclopedia of cyber behavior (pp. 735-753). IGI Global.

[24]Luin, D. (2004). Družbeno ekonomski vidiki igralništva in igralniški turizem. Nova Gorica: 
Turistica-Visoka Šola Za Turizem.

[25]Maida, J. (2016). Top 5 Trends Impacting the Global Online Gambling Market Through 2020: Technavio. Retrieved 7 September 2017, from http://www.businesswire.com/news/ home/20160921005570/en/Top-5-Trends-Impacting-Global-Online-Gambling

[26]Makarović, M., Macur, M., \& Rončević, B. (2011). POLICY CHALLENGES OF PROBLEM GAMBLING IN SLOVENIA. Ljetopis Socijalnog Rada/Annual of Social Work, 18(1).

[27]Mancini, Q., \& Tonucci \& Partners. (2016). Gaming in Italy: overview.

[28]Nolan, B. (1994). Data analysis: an introduction. Dunfermline, United Kingdom: Polity.

[29]Oldroyd, K. (2017). Global Internet Gambling Expected to Grow Exponentially.

[30]Otvoren prvi internet casino u Hrvatskoj. (2015).

[31gPempus, B. (2016). Global Gambling Market To Reach \$635 Billion By 2022. Retrieved 7 September 2017, from http://www.cardplayer.com/poker-news/20865-global-gambling-market-toreach-635-billion-by-2022

[32]Puljiz, H. (2015). Evo koliko Hrvati godišnje spiskaju na 'poker aparatima'.

[33]Republic of Croatia Croatian Bureau of Statistics. (2017). Statistical information.

[34]Republic of Slovenia Statistical Office. (2017). Data.

[35]Republika Slovenija Ministarstvo za finance. (2017). Posebne igre na srečo, Izvleček iz registra koncesionarjev za igralnico.

[36]Ricijaš, N., Dodig Hundrić, D., Huić, A., \& Kranželić, V. (2016). Youth Gambling in CroatiaFrequency of Gambling and the Occurrence of Problem Gambling. Kriminologija \& Socijalna Integracija: Časopis Za Kriminologiju, Penologiju i Poremećaje u Ponašanju, 24(2), 48-72.

[37] Schwartz, W., \& Schwartz Huber-Medek und Partner. (2016). Gaming in Austria: overview.

[38] gStewart, D. O., \& Gray, L. L. P. (2011). Online gambling five years after UIGEA. Washington, DC: American Gaming Association.

[39]Tableau. (2014). Visual Analysis Best Practices. Tableau Software, 41. Retrieved from http:// www.tableausoftware.com/learn/whitepapers/tableau-visual-guidebook

[40] The world's biggest gamblers. (2017). Retrieved 7 September 2017, from https://www.economist. com/blogs/graphicdetail/2017/02/daily-chart-4

[41] Washington, C. (2016). Italy's Gambling Market Up 11.4\% in 2016. Retrieved 8 September 2017, from https:/www.toppokersites.com/news/italys-gambling-market-up-11-4-in-2016/4920

[42] Wood, L. (2017). Global Casino Gaming Market 2017-2021: Increase in the Popularity of Gambling Apps and Social. Retrieved 7 September 2017, from http://www.prnewswire.com/newsreleases/global-casino-gaming-market-2017-2021-increase-in-the-popularity-of-gambling-appsand-social-gambling---research-and-markets-300387138.html 